\title{
KEDUDUKAN MAZHAB SYAFI'I DALAM PERKEMBANGAN AHLUS SUNNAH DI NEGERI PERLIS
}

\author{
Oleh: \\ Saadan Man*
}

\begin{abstract}
Perlis is known as the only state in Malaysia which declares itself as not bound to adhere to the Shafi ite madhhab in practising Islamic law. This is a result of Islamic reformism, better known in Perlis as Ahlus Sunnah, which is fairly dominant in the state. In spite of this fact, one might see so many Islamic practices done by local Muslims which are regularly associated to the Shafi ite madhhab. This proves that the influence of Shafi'ite madhhab is still prevalent in the state. This article shall examine to what extent the madhhab survives in the rapid growth of Islamic reformism in Perlis Muslim society.
\end{abstract}

\section{PENDAHULUAN}

Tidak seperti negeri-negeri lain di Malaysia, Perlis adalah satusatunya negeri yang tidak terikat dengan mazhab Syafi'i. Namun demikian, sejarah telah membuktikan bahawa pengaruh mazhab Syafi' $i$ telah menunjangi negeri ini terlebih dahulu sebelum aliran Islah atau lebih dikenali sebagai aliran Sunnah mendominasi negeri ini semenjak era 1950-an. Perkembangan Islam di negeri

* Pensyarah Kanan, Jabatan Fiqh \& Usul, Akademi Pengajian Islam, Universiti Malaya, Kuala Lumpur. 
ini terlebih dahulu dicorakkan oleh pemikiran fiqh mazhab Syafi'i, iaitu semenjak beratus-ratus tahun dahulu, berbanding dengan aliran Sunnah yang baru menguasai negeri ini hampir 5 dekad kebelakangan ini. Justeru, secara umumnya, dilihat bahawa pengaruh mazhab Syafi'i di dalam masyarakat di negeri ini masih agak kukuh.

Situasi ini juga didorong oleh faktor keterbukaan aliran pemikiran Sunnah di negeri ini dalam fiqh yang membenarkan dan mengambilkira pandangan-pandangan dalam semua mazhab ketika menentukan hukum, di mana situasi ini turut memberi peluang kepada pengaruh mazhab Syafi' $i$ untuk terus berkembang. Di samping itu, pemikiran dan amalan mazhab ini sudah agak lama sebati sama ada di kalangan para agamawan mahupun dalam kalangan masyarakat umum tempatan. Ini boleh dilihat dengan agak ketara dalam beberapa aspek tertentu seperti dalam amalan masyarakat, sistem perundangan Islam dan pendidikan formal dan tidak formal. Penulisan ini akan cuba menganalisis sejauh manakah pengaruh, kedudukan dan survival mazhab Syafi'i di negeri ini melalui aspek-aspek tersebut.

\section{SEJARAH PERTUMBUHAN MAZHAB SYAFI'I DI PERLIS}

Secara umumnya, sejarah berhubung proses pertapakan dan pemantapan mazhab Syafi'i di negeri Perlis boleh dilihat melalui beberapa dimensi: (i) penyampaian Islam oleh pendakwah dari luar (ii) faktor kepimpinan (iii) sistem pentadbiran agama Islam (iv) pendidikan dan seterusnya amalan berterusan dalam masyarakat.

\section{i. Penyampaian Islam Oleh Pendakwah Luar}

Sejarah perkembangan mazhab Syafi'i di negeri Perlis berkait rapat dengan sejarah kedatangan awal Islam ke negeri ini. Maklumat dan fakta sejarah berhubung kedatangan Islam di negeri Perlis agak sukar diperolehi. Ini kerana sejarah negeri ini secara khususnya hanya bermula pada pertengahan kurun ke 19. Oleh kerana negeri Perlis dahulunya merupakan sebahagian daripada negeri Kedah iaitu sehingga tahun 1834, maka kedatangan Islam ke negeri ini perlu dirujuk kepada sejarah kedatangan Islam ke 
negeri Kedah. Mengikut catatan sejarah, tarikh terawal Kedah mula menerima pengaruh Islam pada sekitar abad ke $10 \mathrm{M} .{ }^{1}$ Para sejarawan menyebut bahawa pada sekitar tarikh berkenaan telah berlaku hubungan dagangan antara Asia Barat dengan Kedah yang mungkin membawa kepada penerimaan Islam. ${ }^{2}$ Penyebaran Islam di sini juga dikatakan telah dimulakan oleh pedagang-pedagang dari Tanah Arab khususnya dari Hadhramaut, Yaman. ${ }^{3}$

Pedagang-pedagang dari Hadhramaut ini, seperti yang dimaklumi merupakan penganut mazhab Syafi'i yang setia. Fakta ini memungkin sebuah kesimpulan bahawa oleh kerana masyarakat Melayu pada ketika itu mengenali dan memeluk agama Islam di tangan pendakwah-pendakwah yang bermazhab Syafi' $i$, sudah tentulah anutan dan amalan mereka juga adalah mengikut mazhab Syafi‘ $i$.

\section{ii. Faktor Kepimpinan}

Sejarah Perlis juga sering dikaitkan dengan sejarah keturunan Syed bergelar Jamalullail dari Hadhramaut, Yaman. Disebut bahawa keturunan asal Raja Perlis, Syed Ahmad Jamalullail tiba di Kedah dari Hadhramaut pada 1735. Puteranya Syed Harun Jamalullail telah berkahwin dengan Tunku Safiah, puteri Sultan Dhiauddin yang menjadi pemangku Sultan Kedah pada ketika itu. Sultan Dhiauddin telah menyerahkan mukim Arau kepada Syed Harun dan beliau menjadi penghulu Arau yang pertama. Setelah meninggal dunia pada 1825 , beliau digantikan oleh puteranya Syed Hussain Jamalullail. Apabila Siam menjajah Kedah, mereka membahagikan Kedah kepada tiga wilayah iaitu Kedah, Perlis dan Kubang Pasu. Dengan pembahagian ini, Raja Siam telah melantik

1 Ini berdasarkan tarikh yang tercatat pada batu nisan Sheikh Abdul Qadir Ibn Husin Shah Alam yang dijumpai pada tahun 1962 di Tanjung Aris, Langgar, Kedah. Batu nisan ini bertarikh 290H bersamaan 920M. Lihat Abdullah Ishak (1989), Islam di Nusantara. Kuala Lumpur: BAHEIS, hh. 44-45.

2 Ibid., h. 45.

3 Sebagai contoh Maharaja Derbar II, raja Kedah diislamkan oleh Sheikh 'Abd Allah bin Sheikh Ahmad al-Qaumīr al-Yamani pada 531H/1136M. Lihat ibid., h. 60. 
Syed Hussain Jamalullail sebagai Raja Perlis yang pertama. ${ }^{4}$ Sejak dari itu pemerintahan kerajaan beraja di Perlis diwarisi oleh keturunan Jamalullail.

Oleh kerana umum memaklumi bahawa Raja adalah berasal dari Hadhramaut dari kalangan pengikut Ahl al-Sunnah wa al-Jama 'ah yang bermazhab Syafi' $i,{ }^{5}$ secara tradisinya, sudah tentulah rakyat jelata di negeri ini menganut mazhab yang sama.

\section{iii. Pentadbiran Agama Islam}

Tidak lama setelah sistem pemerintahan beraja diinstitusikan di negeri Perlis, jawatan Kadi Besar di Perlis mula diperkenalkan pada 1873 bagi memperkukuhkan kepimpinan dan pentadbiran negeri. Penyandang pertamanya adalah seorang ulamak berketurunan Syed dari Hadhramaut, iaitu Sayyid Muḥammad al-Ḥaddād ${ }^{6}$ yang semestinya bermazhab Syafi'i. Gandingan antara pemerintah iaitu Raja dan penguasa agama iaitu kadi yang bermazhab Syafi' $i$ memastikan Islam yang berkembang di negeri ini dicorakkan oleh pemikiran mazhab tersebut.

Selepas era Sayyid Muḥammad al-Ḥaddād, jawatan kadi dipegang oleh Haji Muhammad b. Haji Abdul Latif, dan kemudiannya digantikan oleh anak beliau iaitu $\mathrm{Hj}$. Muhammad Noor b. Hj. Muhammad. Kemudiannya beliau dilantik menjadi mufti pertama negeri Perlis iaitu dari tahun 1920-1941. Kesemua tokoh ini adalah dari kalangan mereka yang berpegang teguh dengan mazhab Syafi' ${ }^{\circ}{ }^{7}$ Penubuhan Jabatan Agama Islam pada 1920 dan Majlis Agama Islam dan Adat Istiadat Melayu Perlis pada 1948 menyaksikan bahawa badan-badan pentadbiran agama Islam ini diterajui oleh mereka yang bermazhab Syafi'i.

4 Beliau menjadi Raja yang memerintah negeri Perlis dari tahun 18431873. Lihat Buyong Adil (1981), Sejarah Perlis. Kuala Lumpur: Dewan Bahasa dan Pustaka, hh. 4-8.

5 Mahayudin Haji Yahaya (1984), Sejarah Orang Syed di Pahang. KL: Dewan Bahasa dan Pustaka, hh. 4 \& 7.

$6 \quad$ Buyong Adil (1981), op.cit., h. 23.

7 Abdul Rahman Haji Abdullah (1989), Gerakan Islah di Perlis: Sejarah dan Pemikiran. Kuala Lumpur: Penerbitan Pena Sdn Bhd, hh. 20-21. 
Penubuhan Jabatan Agama Islam pada 1920 dan Majlis Agama Islam dan Adat Istiadat Melayu Perlis pada 1948 menyaksikan bahawa badan-badan pentadbiran agama Islam ini diterajui oleh mereka yang bermazhab Syafi'i. Ini terbukti apabila sebilangan tokoh Islah yang memegang jawatan sebagai imam masjid telah dipecat kerana memperkenalkan "ajaran-ajaran baru" yang tidak secocok dengan amalan kebiasaan masyarakat setempat. ${ }^{8}$

\section{iv. Pendidikan}

Pegangan masyarakat terhadap mazhab Syafi' ${ }^{\prime}$ juga diperkukuhkan melalui sistem pendidikan sama ada secara formal dan tidak formal. Seperti negeri-negeri lain, mazhab Syafi'i ini bertapak dengan suburnya di negeri Perlis dengan wujud dan berkembangnya institusi pondok di negeri ini. Seperti yang diketahui, institusi pondok sebagai pusat pengajian Islam terawal yang mengamalkan sistem pengajian tradisional merupakan wasilah utama bagi perkembangan mazhab Syafi'i di alam Melayu ini. Di Perlis keadaan ini tidak terkecuali.

Sistem pendidikan pondok di Perlis telah bermula sejak sekian lama. Sebelum era penjajahan Jepun di Tanah Melayu, terdapat beberapa buah pondok dan madrasah yang masyhur di negeri Perlis, antara lain ialah: ${ }^{9}$

a. Pondok Haji Ibrahim b. Haji Jusoh di Kampung Padang Pauh

b. Pondok Haji Muhammad b. Muhammad Salleh di Kampung Belukar, Arau

c. Pondok Haji Muhammad Rawi di Kampung Tok Peduka, Kangar

8 Sebagai contoh, Tuan Haji Abdul Ghani b. Dato' Sakti, seorang tokoh Islah di negeri ini telah dipecat dari jawatannya sebagai Imam Masjid Kampung Abi pada sekitar tahun 1920-an kerana amalan beliau dalam beberapa perkara berhubung dengan ibadat berbeza dengan amalan biasa yang menjadi tradisi masyarakat. Lihat Syed Hassan Syed Mohamad (1987), “Kertas Kerja Mengenai Perkembangan Ahli Sunnah", h. 25.

$9 \quad$ Lihat Syed Hassan Syed Mohamad (1987), “Kertas Kerja Mengenai Perkembangan Ahli Sunnah", hh. 23-24. 
d. Pondok Haji Yunus b. Haji Salleh di Mata Air

e. Pondok Haji Muhammad b. Haji Saman di Jalan Kaki Bukit

f. Pondok Haji Ishak b. Che Tam di Mata Air

g. Pondok Haji Rejab b. Haji Muhammad di Kampung Darat, Beseri

h. Pondok Haji Ahmad b. Othman di Kampung Belat Batu, Arau

i. Madrasah Haji Taib b. Haji Salleh di Kampung Petai

j. Madrasah Haji Ghazali b. Hj. Muhammad

Seperti yang diketahui, sistem pengajaran dan pembelajaran fiqh di pondok-pondok dan madrasah ini menggunapakai karyakarya penulisan ulamak dalam mazhab Syafi ‘i. Dari sini pengaruh mazhab Syafi'i menjadi begitu dominan dalam masyarakat di sini.

Dalam sistem pendidikan formal pula, sejarah mencatatkan bahawa al-Madrasah al-Diniyyah al-`Alawiyyah yang ditubuhkan pada 1926telahmenjadipusatpendidikan Islamperingkatmenengah terawal di negeri ini. Pengajaran fiqh di sini bertunjangkan kepada mazhab Syafi'i di mana silibusnya diselaraskan dengan sistem pengajaran di Mesir dan mendapat kelulusan dari Universiti AlAzhār. Mudir-mudir yang berkhidmat di madrasah ini kebanyakan didatangkan dari Mesir, khususnya dari tahun 1945 hingga tahun 1959. ${ }^{10}$ Madrasah ini telah memberikan sumbangan yang besar dalam pemantapan pengaruh mazhab Syafi'i dalam masyarakat Islam di negeri ini.

Dari gambaran ini jelas bahawa pengaruh mazhab Syafi' $i$ amat kukuh dan telah berakar umbi dalam masyarakat di sini sejak awal kedatangan Islam lagi. Hakikat ini tidak disangkal oleh sesiapa memandangkan sejarah telah mencatatkan bahawa sebelum kedatangan pengaruh gerakan Islah Islamiyyah ke rantau ini,

10 Seperti Syeikh ‘Abd al-Ḥamid Mușțafā al-Sisis Affandi (1945-1948), Syeikh 'Abd al-Haqq Hamīd al-Jizār (1949-1952), Syeikh Taqii alDīn Qandīl (1952-1956), Syeikh 'Abd al-Barr 'Ațā' Allah (19571959). Lihat Abdul Rahman Abdullah (1987), op.cit., h. 18. 
daerah Nusantara merupakan "zon selamat" bagi mazhab Syafi ‘i sejak berkurun lamanya.

\section{ERA TRANSISI}

Pengaruh dan kedudukan mazhab Syafi'i di Perlis sebelum kemunculan gerakan Islah boleh dikatakan amat kukuh sekali. Situasi ini berterusan sehinggalah datangnya gerakan Islah ke negeri ini pada sekitar 1920-an iaitu sebagai rentetan daripada berkembangnya gerakan Islah Islamiyyah ini muncul di rantau Tanah Melayu ini pada awal kurun ke 20. Sebagai sebuah negeri Tanah Melayu, Perlis turut menerima percikan pengaruh Islah ini.

Terdapat beberapa keterangan tentang tokoh pelopor gerakan Islah di Perlis. Sumber pertama menyebut bahawa gerakan Islah ini dibawa ke negeri Perlis oleh Syeikh Hassan Sarbani yang berasal dari Surabaya pada tahun 1920-an. Beliau telah membuka kelas pengajaran di Arau, tetapi mendapat tentangan hebat dari masyarakat setempat. Beliau kemudiannya berpindah ke Johor dan Pulau Pinang. ${ }^{11}$ Pada tahun 1926 beliau kembali ke Perlis dan kali ini mendapat sokongan dari tokoh pemerintah iaitu Tuan Haji Abdullah b. Ahmad dan seorang ulamak tempatan iaitu Haji Abdul Ghani b. Dato' Sakti. ${ }^{12}$ Gandingan beliau dan Haji Abdul Ghani mula mendapat sambutan masyarakat. Sebuah madrasah dibina di Alor Sena untuk dijadikan pusat pengajaran.

Keterangan lain menyebut bahawa aliran Islah ini dibawa oleh seorang ulamak Indonesia yang bergelar Lebai Kecik dari

11 Menurut kajian, Shukor Mat, seorang pengkaji tempatan, nama sebenar beliau ialah Syeikh Hassan b. Ahmad, datang ke Perlis sebelum 1916. Oleh kerana difitnah dengan tuduhan sebagai pembawa ajaran baru, beliau dikatakan telah diusir oleh Raja Syed Alwi keluar dari Perlis. Lihat Shukor Mat (2000), As-Sunnah Di Perlis. Kangar: Media One Publication, hh. 7-8.

12 Lihat Syed Hassan Syed Mohamad (1987), op.cit., h. 24. 
Indonesia yang datang ke negeri ini pada sekitar tahun $1925 .{ }^{13}$ Akibat pengajaran beliau yang berbeza dari kefahaman biasa masyarakat, timbul tuduhan bahawa beliau mengetuai satu kaum yang membawa agama baru dan tidak lagi mahu berpegang kepada agama dan adat resam datuk nenek yang diwarisi turun temurun. ${ }^{14}$ Walaupun masyarakat setempat tidak berminat dengan ajaran yang dibawa beliau, masih ada sebilangan penduduk yang berguru dengan beliau. ${ }^{15}$

Tanpa mengambilkira siapakah yang sebenarnya yang mempelopori gerakan Islah di Perlis ${ }^{16}$ aliran ini semakin mendapat tempat dalam kalangan masyarakat dan mulai mempengaruhi ramai dari kalangan mereka yang memegang tampuk pemerintahan negeri. Antara tokoh politik yang sering disebut sebagai penggerak utama gerakan Sunnah di Perlis pada tahun-tahun 1930an hingga 1950an ialah Haji Ahmad b. Haji Muhammad, Dato' Wan Ahmad b. Wan Daud dan Dato' Sheikh Ahmad b. Mohd Hashim. Mereka bertiga inilah yang bertanggungjawab membawa masuk Syeikh

13 Lihat Ijtimak Al-Sunnah Perlis: Kumpulan Lima Kertas Kerja Ijtimak (1986), h. 90. Fakta ini mungkin berasaskan catatan peribadi Dato' Wan Ahmad b. Wan Daud, seorang tokoh penggerak aliran Islah di Perlis, dalam sebuah buku catatan yang diberi tajuk "Agama dan Zakat di Perlis.” Buku catatan ini disimpan di dalam Koleksi Perlis di Perpustakaan Awam Negeri Perlis. Kajian oleh Shukor Mat mendapati bahawa Lebai Kecik atau nama sebenarnya Abdul Manaf b. Abdullah bukanlah individu pertama yang membawa aliran Islah ke negeri ini kerana menurut kajiannya, Lebai Kecik datang pada sekitar tahun 1930an, lewat dari kedatangan Syeikh Hassan. Lihat Shukor Mat (2000), op.cit., h. 2.

14 Buku catatan Dato' Wan Ahmad, op.cit., (t.h.)

15 Ijtimak Al-Sunnah Perlis (1986), op.cit., h. 90.

16 Dalam menganalisis sejarah perkembangan gerakan Islah di Perlis, Abdul Rahman Haji Abdullah telah membahagikannya kepada beberapa fasa, iaitu fasa pembentukan (1920an-1940); fasa kebekuan (1941-1945); fasa pemulihan 1945-1960; fasa pergolakan (19601970) dan perkembangan mutakhir. Menurutnya, gerakan Islah ini mencapai kemuncaknya pada fasa pemulihan iaitu dari tahun 19451960. Lihat Abdul Rahman Haji Abdullah (1987), op.cit., hh. 2044. 
Abu Bakar Asyaari dari Pulau Pinang untuk menggiatkan dakwah Sunnah di Perlis pada tahun 1936. Setelah mengalami fasa kebekuan buat beberapa ketika kerana kesan penjajahan Jepun, gerakan ini mendapat nafas baru pada lewat 1940an di mana Syeikh Abu Bakar Asyaari telah memainkan peranannya sebagai penggerak dan tokoh pemimpin gerakan Sunnah dengan lebih berkesan melalui jawatannya sebagai Imam Besar Masjid Alwi, Kangar. Di sini beliau telah menjalankan usaha dakwah secara lebih bersistematik melalui kuliah-kuliah pengajaran dan melalui karya-karya penulisan beliau. Beliau disifatkan sebagai seorang tokoh yang berkarisma, berani, tegas dan bijaksana. Dengan sifatsifat ini beliau telah berjaya mempengaruhi masyarakat di mana kuliah pengajarannya sentiasa mendapat sambutan yang amat menggalakkan. ${ }^{17}$

Dengan pengaruhnya yang semakin kukuh, aliran Sunnah di Perlis membuka satu lagi episod yang penting iaitu dengan termaktubnya ideologi Islah ini di dalam perundangan negeri, seperti Undang-Undang Tubuh Negeri Perlis dan Undang-undang Pentadbiran Agama Islam Negeri Perlis. Undang-undang Tubuh Negeri Perlis (Bahagian II: Agama Negeri) misalnya menyebut: ${ }^{18}$

5 (1): "Agama bagi negeri ialah agama Islam Ahlus Sunnah

Wal Jama ah seperti telah diamalkan di dalam negeri"

Undang-undang Pentadbiran Agama Islam Perlis pula menyebut: ${ }^{19}$

7(4): "Tatkala Majlis mengeluarkan suatu fatwa dan Jawatankuasa Syariah memberi pendapatnya di bawah ceraian (2) maka hendaklah badan itu mengikut al-Quran dan Sunnah Rasul Allah SAW.."

17 Lihat Haron Din, "Syeikh Abu Bakar Al-Ashaari: Ulamak Tegas dan Berani” dlm. Qiblat, Julai 1976. Lihat Juga Shukor Mat, op.cit., hh.18-24.

18 Perkara 5(1) Undang-undang Tubuh Kerajaan Perlis 1959, (pindaan 1974), h. 4.

19 Perkara 7(4)Undang-undang Pentadbiran Agama Islam Perlis Tahun 1963, h. 5. 
Proses memasukkan fahaman Sunnah dalam sistem perundangan negeri menjadi agak mudah disebabkan tokoh-tokoh politik negeri seperti yang disebut sebelum ini adalah terdiri dari kalangan pendukung dan penyokong aliran ini. Dalam masa yang sama aliran ini mendapat restu dan perkenan dari DYMM Tuanku Raja Perlis selaku ketua agama Islam di negeri ini. Dengan termaktubnya ia dalam perundangan negeri, maka negeri Perlis telah menjadi sebuah negeri yang berbeza dari negeri lain kerana ia tidak lagi terikat dengan mazhab Syafi'i dalam aspek-aspek dan urusan pentadbiran agamanya. Sejak itu, dominasi mazhab Syafi' $i$ di negeri ini terhakis dan pengaruhnya kelihatan dikekang oleh perundangan.

Walaupun pengaruh gerakan Sunnah di Perlis ini kadang-kala menjadi lemah dan lesu, terutamanya setelah Syeikh Abu Bakar Ashaari meninggal dunia pada 1970, kesinambungan gerakan ini sentiasa berterusan. Salah satu perkara yang unik di negeri ini ialah gerakan Islah ini sentiasa mendapat sokongan padu dari pemerintah khususnya dari setiap Menteri Besarnya. Ini merupakan satu tradisi yang diwarisi sejak Menteri Besar pertama dilantik iaitu Datuk Sheikh Ahmad b. Mohd Hashim pada 1959 sehinggalah Menteri Besar Perlis sekarang iaitu Dato' Seri Shahidan Kassim. ${ }^{20}$

Kekuatan gerakan Sunnah di Perlis ini bukanlah terletak pada individu-individu dalam politik dan kerajaan negeri sahaja. Sebaliknya terdapat beberapa pihak lain yang memainkan peranan penting sebagai penggerak aliran Islah di Perlis. Ini termasuklah Persatuan al-Islah Perlis, ABIM Perlis, institusi-institusi agama dan tokoh-tokoh ulamak tertentu.

20 Dalam perkembangan semasa, Dato' Seri Shahidan Kasim dilihat begitu banyak sekali melakukan usaha untuk memperkasakan gerakan Islah di Perlis. Melalui kerajaan negeri yang diterajuinya puluhan seminar bertemakan pemikiran Islah telah dianjurkan sejak beliau memegang jawatan menteri besar. Antara usaha terpenting beliau untuk memartabatkan pemikiran Sunnah di Perlis ialah mempergiatkan dan memperluaskan aktiviti dakwah Islah di negeri ini dan melantik Dr. Mohd Asri Zainul Abidin seorang tokoh muda sebagai Mufti Perlis bagi menyuntik kekuatan gerakan Sunnah di negeri Perlis. Beliau juga memperkenalkan gelaran baru tidak rasmi bagi negeri Perlis iaitu Darul Sunnah menggantikan gelaran tradisi Indera Kayangan. 


\section{SURVIVAL MAZHAB SYAFI'I DI PERLIS}

Dalam perkembangan gerakan atau aliran Sunnah di Perlis ini, mazhab Syafi' $i$ kelihatan seolah-olah terpinggir walhal dahulunya mazhab ini begitu mantap sekali di Perlis. Umum mungkin mempersoalkan, benarkah apabila gerakan Sunnah mendominasi negeri ini maka pengaruh mazhab lenyap begitu sahaja. Persoalan ini adalah satu isu yang menarik untuk dibincangkan. Bagi tujuan ini, ada baiknya jika kita meneliti perkara ini dari beberapa sudut pandang, iaitu dari aspek pendidikan, perundangan dan amalan masyarakat.

\section{i. Pendidikan Agama}

Sebagaimana yang disebut sebelum ini, pengaruh mazhab Syafi'i di Perlis banyak disebarluaskan melalui institusi pondok dan madrasah. Walaupun kewujudan institusi pondok di Perlis kini telah menjadi sejarah, pengaruh mazhab ini masih terus berkembang melalui institusi pendidikan, tetapi kali ini diambil alih peranannya oleh sekolah-sekolah sama ada sekolah kerajaan atau sekolah agama rakyat yang rata-rata kini diambilalih oleh bawah kerajaan pusat sebagai Sekolah Agama Bantuan Kerajaan (SABK).

Jika ditinjau dari aspek pendidikan formal di sekolah-sekolah terutamanya sekolah menengah dan juga sekolah rendah, kurikulum dan silibus subjek pendidikan Islam khususnya pembelajaran fiqh yang digunapakai di negeri ini sama dengan negeri-negeri yang lain yang mengadaptasikan hukum-hukum fiqh dari mazhab Syafi'i. Justeru, kanak-kanak dan murid-murid Islam di negeri ini terdedah dengan hukum-hukum dari mazhab Syafi ‘ i sejak kecil lagi iaitu bermula dari sekolah rendah. Mereka seterusnya membesar dengan kefahaman hukum dari mazhab yang sama apabila mempelajari fiqh di peringkat menengah. Kurikulum di sekolah agama juga, termasuk sekolah yang dimiliki oleh Kerajaan Negeri Perlis melalui Yayasan Islam Perlis iaitu Madrasah Alawiyah di Arau mempunyai silibus fiqh yang berteraskan mazhab Syafi‘i. Beberapa sekolah agama rakyat lain seperti Madrasah Islahiyah Bohor Mali dan Ma'had al-Diniyyah (MADI) di Jejawi turut mempunyai silibus yang sama yang diluluskan oleh Jabatan Agama Islam Perlis selaras dengan kehendak kementerian. 
Fenomena ini bukanlah sesuatu yang luar biasa memandangkan sukatan pelajaran ini ditentukan oleh pihak Kementerian Pelajaran Malaysia, manakala pihak lain termasuk kerajaan negeri tidak mempunyai apa-apa bidang kuasa untuk campurtangan. Justeru, kanak-kanak dan remaja yang tidak didedahkan dengan pemikiran Sunnah akan menerima pakai fiqh Syafi 'i sehingga mereka dewasa. Situasi ini memberi kredit terhadap mazhab Syafi 'i dan memastikan pengaruh mazhab ini berkekalan dalam masyarakat. Seperti mana pendidikan merupakan wasilah utama berkembangnya pengaruh mazhab Syafi'i di Perlis, pendidikan juga telah mengekalkan pengaruh mazhab ini di negeri ini. Dalam aspek pendidikan ini, gerakan Sunnah di Perlisyangmenitikberatkan fiqhtanpa sempadan hanya berupaya menumpukan kepada kelas-kelas pengajian melalui program-program tafaqquh yang dianjurkan sama ada di masjid-masjid atau pusat-pusat pengajian seperti yang dianjurkan oleh Persatuan al-Islah Perlis dan Jam 'iyyah Imam-Imam Masjid. Kelas-kelas umum ini kebiasaannya dihadiri oleh mereka yang berminat dari kalangan orang dewasa sahaja. Kelihatan situasi ini seolah-olah gerakan Sunnah di Perlis mempunyai pengaruh yang agak terhad dalam aspek pendidikan walaupun programprogram umum ini sering mendapat sambutan yang baik dari kalangan masyarakat. Namun jika mereka menubuhkan sekolah yang khusus sekalipun, mereka tidak mempunyai kebebasan dari sudut penentuan silibus. Dilema ini menyebabkan mereka tidak mempunyai pilihan lain melainkan memberi tumpuan kepada penganjuran program-program dan kelas tafaqquh umum.

\section{ii. Perundangan Islam}

Sebagaimana yang dimaklumi, kuasa menggubal undang-undang berhubung hal ehwal agama Islam di negeri tertakluk di bawah bidang kuasa negeri. Jelas dengan peruntukan yang diberikan di bawah Perlembagaan Persekutuan ini, negeri berhak mengadakan apa juga undang-undang berkaitan agama selagi tidak menjangkaui bidang kuasa yang ditentukan. Dalam hal ini, negeri Perlis boleh mewujudkan undang-undang atau enakmen yang mengadaptasikan hukum-hukum dari al-Quran, Sunnah Nabi SAW dan pandanganpandangan mazhab yang ditarjihkan mengikut prinsip aliran Sunnah sebagaimana yang diamalkan di negeri ini. 
Walaubagaimanapun, dari penelitian yang dilakukan, kebanyakan undang-undang atau enakmen berkaitan agama yang ada di Perlis telah diselaraskan dengan undang-undang di negeri-negeri lain di Malaysia, di mana kebanyakan peruntukannya adalah berasaskan kepada hukum-hakam dari mazhab Syafi'i, melainkan ada pengecualian di satu dua tempat. ${ }^{21}$

Dengan penyelarasan perundangan Islam antara negeri ini, jelas kelihatan bahawa pengaruh mazhab Syafi'i masih lagi mendominasi dalam aspek ini. Walaupun kerajaan negeri berkuasa untuk tidak terikat dengan mazhab Syafi'i dalam undang-undang, nampaknya dalam hal ini mereka tidak mahu menggunakan kuasa tersebut. Dalam hal ini, prinsip pemikiran Islah atau Sunnah di negeri hanya terbatas diaplikasikan dalam proses mengeluarkan fatwa sahaja. ${ }^{22}$

\section{iii. Amalan Masyarakat}

Seseorang dari luar yang datang ke Perlis dan bersembahyang di Masjid Negeri di Arau atau di Masjid Alwi di Kangar akan mendapati pelbagai bentuk perbezaan dalam solat berbanding di negeri lain, seperti Bismillāh sirr, tiada bacaan Qunut dalam solat Subuh, tiada doa nyaring beramai-ramai selepas solat jamaah, tiada talaffuz bi al-niyyah, tiada azan dua kali semasa solat Jumaat dan seumpamanya. Tiada tahlil, bacaan Yasin beramai-ramai pada malam Jumaat dan tiada talkin selepas mengebumikan jenazah.

Bagaimanapun jika seseorang itu pergi dengan lebih jauh lagi, terutama di kawasan-kawasan kampung berhampiran Kedah atau di kawasan lebih utara menghala ke sempadan Thailand, seseorang mungkin mendapati keadaan yang berbeza. Amalan-amalan yang

21 Sebagai contoh peruntukan perceraian talak tiga sekali lafaz jatuh satu dalam Enakmen Keluarga Islam Perlis dan kelonggaran berpoligami. Temubual dengan Timbalan Mufti Perlis, SF. Us. Roslan Esa pada 4 Jun 2007 di Jabatan Mufti Perlis, Bangunan Yayasan Islam Perlis, Kangar.

22 Lihat Mohd Akram Dahaman@Dahlan (2005) "Metode Fatwa Jawatankuasa Syariah Negeri Perlis: Kajian Berasaskan Fatwa-fatwa Tahun 1990-2000" disertasi Sarjana Jabatan Fiqh \& Usul Universiti Malaya, hh. 98-119. 
biasanya dikaitkan dengan amalan Syafi'iyyah masih diamalkan dalam masyarakat terutamanya di surau-surau. Tahlil dan bacaan Yasin masih diamalkan, qunut Subuh dibaca dan talkin dibaca untuk jenazah. Walaupun kerajaan negeri melalui Jabatan Agama Islam Perlis dan Jabatan Mufti sentiasa memantau, namun amalanamalan ini masih kuat diamalkan oleh sebahagian masyarakat.

Kajian yang dilakukan oleh Mohd Radzi Othman et.al. pada tahun 1991 mendapati bahawa $76.5 \%$ responden bersetuju dengan aliran Sunnah di Perlis, manakala 23.5\% lagi tidak bersetuju. ${ }^{23}$ Kajian ini menunjukkan bahawa secara umumnya aliran Sunnah di Perlis telah diterima masyarakat umum. Ini bertentangan dengan apa yang ditegaskan oleh Abdul Halim El-Muhammady dalam karyanya Adab Berijtihad dan Berikhtilaf Mengikut Syari at, bahawa "majoriti masyarakat awam di Perlis masih mengikuti mazhab Syafi ‘i dalam amalannya hari-hari." ${ }^{24}$

Menurut Timbalan Mufti Perlis, SF. Us. Roslan Esa, nisbah pengikut Sunnah dan pengikut mazhab Syafi'i di Perlis adalah 50:50 $0^{25}$, satu jumlah yang menafikan dominasi satu pihak ke atas satu pihak yang lain. Observasi penulis pula semasa melakukan kajian pada tahun 2005-2006 pula mendapati bahawa 1/3 daripada imam-imam masjid di Perlis masih melakukan amalan-amalan yang dikaitkan dengan mazhab Syafi'i seperti membaca Bismillah jahr dan berwirid nyaring selepas solat jamaah. ${ }^{26}$

Melalui kajian-kajian dan pendapat-pendapat yang dilontarkan di atas, walaupun tidak selaras antara satu sama lain, ia

23 Lihat Mohd Radzi Othman \& O.K. Rahmat Dato Baharuddin (1991), Laporan Penyelidikan Berhubung Gerakan Pembaharuan Islam di Negeri Perlis dan kaitannya Dengan Gerakan Pembaharuan Islam di Negeri-Negeri Lain di Dalam Malaysia, h. 402.

24 Abdul Halim El-Muhammady (2001), op.cit., h. 67.

25 Temubual dengan Timbalan Mufti Perlis, SF. Us. Roslan Esa, op.cit.

26 Observasi di 30 buah masjid di Perlis mendapati 10 daripadanya diketuai Imam yang masih beramal dengan amalan-amalan Syafi'iyyah. Laporan kajian bertajuk Konflik Antara Salafiyyah dan Syafi'iyyah di Perlis: Kesan Terhadap Pemikiran Hukum, Perundangan Islam dan Hubungan Masyarakat, 2006/2006. 
menjelaskan bahawa fahaman dan amalan masyarakat terhadap mazhab Syafi'i terutamanya dalam ibadat masih lagi menebal. Justeru, kesimpulan boleh dirumuskan bahawa secara teori dan praktikalnya, sebahagian dari masyarakat Islam di Perlis masih berpegang teguh dengan mazhab Syafi' $i$ walaupun jumlah sebenar tidak diketahui dengan tepat.

\section{KESIMPULAN}

Kedatangan Islam di negeri-negeri di Tanah Melayu sejak awal lagi telah dicorakkan oleh pemikiran mazhab Syafi' $i$, dan negeri Perlis juga tidak terkecuali dari hal ini. Walaupun gerakan Islah telah memecahkan dominasi pemikiran Syafi'i dalam masyarakat, ia tidak berjaya menguasai keseluruhan masyarakat, sebaliknya dalam aspek-aspek tertentu, ia masih lagi dapat menembusi benteng Syafi iyyah khususnya dalam pengajaran fiqh melalui sistem dan kurikulum pendidikan agama secara formal dan juga perundangan. Justeru, walaupun ada kedengaran kata-kata bahawa mazhab Syafi'i tidak lagi releven di Perlis, realitinya, ia masih lagi utuh dan diamalkan oleh sebahagian masyarakat di negeri ini. Situasi ini dijangka berterusan kerana arus perdana masyarakat di negeri-negeri lain yang berpegang kepada mazhab Syafi' $i$ adalah begitu ampuh dan sukar digugat dan ini memberikan impak sama ada secara langsung atau tidak langsung kepada negeri Perlis. 
Jurnal Fiqh: No. 4 (2007) 141-156 